\title{
On the intellectual content of Greek nationalism: Paparrigopoulos, Byzantium and the Great Idea
}

\author{
Paschalis M. Kitromilides*
}

A conventional view in the historiography of modern Greece tends to connect the origins of Greek nationalism, what is usually described as the Great Idea, with attitudes and aspirations dating from the late Byzantine period, specifically from the period of decline after 1204 , which witnessed the rise of millenarian hopes for the recovery of Constantinople by the Orthodox heirs of the Eastern Roman Empire. This view, which has been propounded by Byzantinists, including such distinguished authorities as D. A. Zakythinos, A. A. M. Bryer and Hélène Ahrweiler, ${ }^{1}$ appears to suggest that the expressions of Greek nationalism in the nineteenth and early twentieth centuries may be placed in the same historical continuum as the intellectual and psychological reactions to the destruction of Byzantine power in Asia Minor after the battle of Manzikert in $1071,{ }^{2}$ the capture of Constantinople by the Crusaders in 1204, the fall of the empire in 1453 and of Trebizond in 1461. The same historical continuum also comprises the expressions of the hope for redemption of the Christian people from infidel captivity during the centuries of Ottoman rule. This latter view, which connects the origins of

* I am grateful to George L. Huxley and Peter Mackridge, Ioanna Petropoulou and Thanos Veremis for reading and commenting on earlier drafts of this paper. For their comments at the original presentation of the paper, which helped me to clarify certain points in the text, I am indebted to Judith Herrin and Costa Carras.

${ }^{1}$ D. A. Zakythinos, Metaryzantina kai Nea Ellinika (1978), 447-63 and The Making of Modern Greece from Byzantium to Independence (Oxford, 1976), 192-8; A. A. M. Bryer, 'The Great Idea', History Today, 15 (3) (March 1965), 513-47; H. Ahrweiler, L'idéologie politique de l'empire byzantin (Paris, 1975), 107-14. See also I. K. Voyatzidis, 'La Grande Idée', 1453-1953. Le cinq-centième anniversaire de la prise de Constantinople (29 May 1953), 279-87.

${ }^{2}$ Cf. S. J. Vryonis, Jr, The Decline of Medieval Hellenism in Asia Minor and the Process of Islamization from the Eleventh through the Fifteenth Century (Berkeley, 1971), 408-38.

From Byzantium and the Modern Greek Identity, ed. David Ricks and Paul Magdalino. Copyright C 1998 by the Centre for Hellenic Studies, King's College London. Published by Ashgate Publishing Ltd, Gower House, Croft Road, Aldershot, Hampshire, GU11 3HR, Great Britain. 


\section{PASCHALIS M. KITROMILIDES}

the Great Idea with the popular traditions of the Tourkokratia, appears in the work of scholars of Greek folklore and popular culture. ${ }^{3}$

An extensive and influential literature on Greek history and culture is premised on such views, contributing to a general inability to appreciate the specificity of phenomena connected with distinctly modern historical experiences such as the construction of a modern state in nineteenth-century Greece. In this paper I should like to place a few question marks against the validity of the conventional approach to the Great Idea. I wish to suggest that what I have briefly sketched as the conventional view essentially abolishes the specificity of Greek nationalism as a distinct political and intellectual phenomenon connected with the formation, consolidation and legitimation of the Greek state. In this connection I should like to point out that we need to look at the Great Idea as an ideological expression of the Greek state and to interpret it in the light of social and cultural preconditions having to do with the cultivation of identity in the process of nationbuilding in nineteenth-century Greece.

After these methodological preliminaries it might be useful to turn to a reconsideration of the sources themselves. Customarily the Great Idea as a term and as a framework of ideological discourse is connected with the famous address by Ioannis Kolettis in the Greek National Assembly on 14 January 1844. This is correct. Nevertheless, while the coinage of the term 'Great Idea' is inextricably connected with Kolettis's speech, a few months earlier an almost identical phrase had been used by the poet Alexander Soutsos in a work published in $1843 .{ }^{4}$ Let me quote the relevant passage:

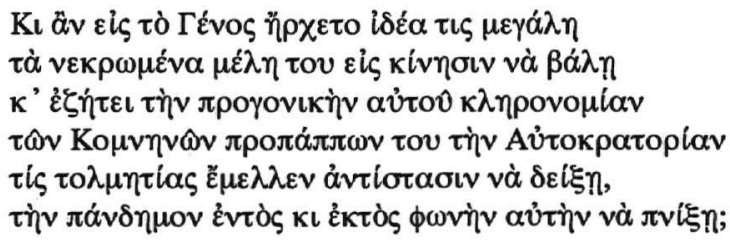

And if there were to come to the Race some great idea of setting its lifeless limbs in motion and if it sought its ancestral heritage, the empire of its Comnene great-grandfathers, what rash spirit would show resistance to this and smother this voice of all the people within and without

[Greece's borders]?

${ }^{3}$ Most notably N. G. Politis, Meletai peri tou viou kai tis glossis tou ellinikou laou (1904), 19-27 and commentary in Part II, A, 651-91. See also G. Megas, 'La prise de Constantinople dans la poésie et la tradition populaire', Le cinq-centième anniversaire, 125-33.

${ }^{4}$ In the 'political drama', $O$ Prothypourgos kai o atithasos poiitis (Brussels, 1843), 9-10. See Y. Lefas, O Alexandros Soutsos kai oi epidraseis tou engou tou stous synchronous tou (1979), 27, n.2. 


\section{PAPARRIGOPOULOS AND BYZANTIUM}

The poet talks of a great idea that might come to the nation, an idea which would involve reclaiming its ancestral inheritance, whose specific form is described as the Comnenian Empire. It thus appears that in this early appearance of the phrase the 'great idea' is interpreted as a claim on the Byzantine Empire. Soutsos, however, connects the term 'great idea' with an indefinite pronoun and thus leaves the meaning much more fluid and rather close to usage in everyday speech. In Kolettis's text things are different. Kolettis is concerned with the unity of the Greek nation, both inside and outside the Greek kingdom. ${ }^{5}$ By means of the argument for unity he wanted to combat the positions taken by all those who denied 'heterochthons' like himself a role in Greek politics. The 'great idea', which he connected with this broader sense of Greek nationality, denoted in fact a political programme that involved Greece's cultural and political hegemony in the 'Greek East', not a resurrected Byzantium. In fact, in this famous address, which is rightly considered as marking the birth of the Great Idea, Kolettis remains silent on Byzantium. At that quite early date Byzantium was still, apparently, a rhetorical device of little effectiveness, and as a form of symbolic discourse it had not yet acquired the evocativeness and psychological potency it was later to have in Greek social communication. Kolettis, moreover, was active at a time when the Enlightenment tradition was still present in Greek politics and strong condemnations of Byzantium were still being voiced in Greek intellectual life. His Western education and radical political origins kept him within the orbit of the Enlightenment. ${ }^{6}$ This might explain his silence on Byzantium and the different, mainly cultural, content he ascribed to the Great Idea.

The projection of Byzantium as an integral component of Greek history and of Greek identity was the product of the intellectual labours of one of Kolettis's younger associates, Konstantinos Paparrigopoulos. ${ }^{7}$ In some of his early writings in the mid-1840s Paparrigopoulos echoed the negative attitude toward Byzantium that prevailed among latter-day followers of the Enlightenment. ${ }^{8}$ This predisposition, however, was completely reversed in his later work, which over a period of three decades produced the monumental synthesis of the History of the Greek Nation..$^{9}$ In this work, which could

\footnotetext{
5 This famous text is to be found in I tis Tritis Septemvriou en Athinais Ethniki Synelefsis (1844), 190-94. Cf. the commentary in K. Th. Dimaras, Ellinikos romantismos (1982), 405-18.

${ }^{6}$ Kolettis's connections with pre-revolutionary radicalism were reflected in the suggestion, long made in Greek literary history, that he had been the author of the most radical republican tract of the Greek Enlightenment, Hellenic Nomarchy, published anonymously in 1806.

${ }^{7}$ As a young publicist Paparrigopoulos worked for three months in 1847 on one of Kolettis's newspapers, Ethniki. See K. Th. Dimaras, Konstantinos Paparrigopoulos (1986), 125.

${ }^{8}$ Dimaras, Paparrigopoulos, 123-4.

${ }^{9} \mathrm{~K}$. Paparrigopoulos, Istoria tou ellinikou ethnous (5 vols, 1860-74; second definitive edition, 5 vols, 1885-87). References below are to the second edition.
} 
be characterized without serious risk of exaggeration as the most important intellectual achievement of nineteenth-century Greece, Paparrigopoulos managed to bring Byzantium and Kolettis's conception of the Great Idea together as components of the political culture of 'Romantic Hellenism'. ${ }^{10}$ In Paparrigopoulos's work, the anxiety brought by the Enlightenment into Greek thought in relation to the Byzantine dimensions of Greek history and Greek identity was finally settled in the most magnificent and reassuring way. ${ }^{11}$ His account of Byzantium, nevertheless, is not a mere rhetorical eulogy. He provides the reader with an extensive and substantive acquaintance with Byzantine history, which for him is the history of the Greek people - or rather of the collective historical agent, the Greek nation during the medieval millennium. What Paparrigopoulos had written rather programmatically in 1852 is now set out in the fullest and most imposing way: 'to the Byzantine state we owe the conservation of our language, our religion and more generally of our nationality'. ${ }^{12}$

Paparrigopoulos's account is detailed and critical, informed by his sense of political responsibility, which he feels ought to be the primary criterion for the judgement of political leadership, whether exercised by Byzantine emperors or by contemporary Greek politicians. The narrative of Byzantine history forms the backbone of Paparrigopoulos's work and constitutes its most detailed and extensive part, taking up more or less three of the five volumes of the second and definitive edition of $1885-87$, the last produced in the author's lifetime. It would be tempting, if space permitted, to enliven this account with details from Paparrigopoulos's treatment of particular subjects of Byzantine history, such as the incorporation of Greek pagan literature into the Christian culture of the Empire; ${ }^{13}$ the incidence of heresy in the Church and the role of the state in the crystallization of official Orthodox doctrine in the ecumenical councils; ${ }^{14}$ and Iconoclasm, which for him was a gigantic reform project that constituted the central drama of Byzantine history and whose failure, the reader occasionally senses, was perhaps connected with the eventual decline and fall of the empire. ${ }^{15}$

\footnotetext{
${ }^{10}$ On the meaning of the term cf. C. Mango, 'Byzantinism and romantic Hellenism', Byzantium and its Image (1984), Study I, 40-42.

${ }^{11}$ On this see P. M. Kitromilides, 'Tradition, Enlightenment and Revolution: Ideological change in eighteenth and nineteenth century Greece' (doctoral dissertation, Harvard University, 1978), 94-8. (See now also the Greek translation: Neoellinikos Diafotismos: oi politikes kai koinonikes idees, tr. S. Nikoloudi [1996], 104-9.)

${ }^{12}$ Dimaras, Paparrigopoulos, 171.

${ }^{13}$ Paparrigopoulos, Istoria, II (1886), 590-603, 614-17, 653-9, 675-6, and III (1886), 12-17, 170-77.

${ }^{14}$ Ibid., II, 512-16, 608-10, and III, 703-9.

15 Ibid., III, 360-699. Note especially the author's overall judgement on pp. 698-9, which connects the policies of the iconoclastic emperors with the distant origins of the Reformation.
} 


\section{PAPARRIGOPOULOS AND BYZANTIUM}

What is perhaps surprising to a modern reader of Paparrigopoulos, especially one who, without having read the work, tends to think of it as merely an ideological and essentially rhetorical statement of Greek nationalism, is the attention the author devotes to social, economic and cultural issues in the life of the Byzantine empire and to technical questions in monetary, administrative and religious history. The broad outline of the History is nevertheless set by the narrative of political and military events and struggles, and this endows the work with an epic character which captivates the reader as a story of greatness, high drama and tragedy. In narrating the chronicle of the Byzantine millennium the author's interest remains focused upon ethnological issues, because his deeper concern is to depict the survival and continuous existence of that exceptional historical actor, the Greek nation, 'to ellinikon ethnos', whose presence on the scene of world history he projects from the very first sentence of his five volumes. His concern with the diachronic presence and continuity of the Greek nation, whose trajectories he traces through the millennia, leads Paparrigopoulos to an understanding of the collective protagonist of his work as an immutable and timeless social organism. Thus, though he draws extensively on contemporary European historiography and is well aware of the attempts of German scholarship to interpret ancient Greek mythology and legend, he remains generally indifferent to the theories of ethnogenesis elaborated by comparative philology and ethnology, which dominated the human sciences in Romantic Europe. ${ }^{16}$ Although he posits the continuous existence of the Greek nation since the dawn of history, Paparrigopoulos conveys nevertheless in his narrative a sense of cultural evolution through five successive stages, which comprise ancient, Macedonian, Christian, medieval, and modern Hellenism. Thus the panorama of Greek history is set on a grand scale.

One stylistic aspect of the text is critical to our understanding of the work. Paparrigopoulos talks of Byzantium in entirely familiar terms, not as something distant in chronological and cultural time, but on the contrary as a historical entity which has an intimacy with the society of his own time. The Byzantine past, for him and his audience, is by no means a 'foreign country'. Thus he talks of 'Medieval Hellenism', of the 'Medieval Greek monarchy', of 'our Medieval empire', of 'our emperors', of 'our Medieval forefathers'. This nurtures a sense of intimacy in the reader's mind and contributes to the incorporation of the Byzantine past into the frame of reference of his or her identity. Thus the reader learns to share the author's enthusiasm for Byzantium's achievements and grandeur and follows him in his grief and despair over the empire's decline and destruction. The drama of 1453 becomes a

\footnotetext{
${ }^{16}$ Ibid., I (1885), 53-63, 68-75, 860-76. On the pertinent intellectual climate in Romantic Europe cf. M. Thom, Republics, Nations and Tribes (1995), 212-68.
} 
source of mourning and dejection and the fall of Constantinople is felt as a personal loss, an open wound, an inconsolable sorrow. ${ }^{17}$ Paparrigopoulos's work, however, is not merely a romantic elegy, a lament for Byzantium. It is primarily a Greek epic. Through the feeling of loss the reader is also taught to appreciate the great empire's most admirable achievement: the unification of the Greek nation, the healing of classical Hellenism's bitter disunity, the realization in the bosom of the Christian Empire of that most noble and most elusive of social ideals, national unity, solidarity and cohesion. That greatest of Byzantium's accomplishments Paparrigopoulos extolled as his own greatest lesson to his contemporaries.

In his project to incorporate the Middle Ages into a linear national history Paparrigopoulos was extending the broader historiographical tendency inspired by the sensibility of European Romanticism into Greek cultural life. His work was a pioneering project whose influence was felt beyond the limits of Greek culture. It supplied a model for the historiographical traditions of other Balkan nationalities which followed Greece in the projects of state- and nation-building in the nineteenth century. The recovery and repossession of their nations' medieval past became the primary objectives in the research and writing programmes of Nicolae Iorga and Vasil Zlatarski, who in the early part of the twentieth century attempted to do for the Romanians and the Bulgarians respectively what Paparrigopoulos had done for the Greeks a few decades earlier.

The affinities between the two Balkan national historians and Paparrigopoulos are striking. Thus Iorga produced a ten-volume History of the Rumanians, in which his inspiration from Paparrigopoulos's conception of the successive stages of one unitary line of national evolution through the millennia is clear. Zlatarski's extensive researches on medieval Bulgaria and his attempt to recreate a coherent picture of the medieval past of his people closely parallels Paparrigopoulos's focus on Byzantium and his preoccupation with the ethnological underpinnings of the medieval Greek state.

Paparrigopoulos's work provoked considerable criticism in intellectual and academic circles, ${ }^{18}$ but it had an immediate broader social appeal rare in an academic work. The Greek state authorities and the spokesmen of a broad spectrum of public opinion acclaimed the work, supported its successive reprints and new editions and promoted its distribution effectively. The pertinent evidence assembled by Dimaras's monograph provides eloquent testimony to the fact that the History of the Greek Nation responded to profound needs and cravings in Greek society and collective consciousness. ${ }^{19} \mathrm{It}$

${ }^{17}$ Ibid., V (1887), 336-434, esp. 423-34. Cf. also pp. 435-42: 'The historical significance of the Fall of Constantinople'.

${ }^{18}$ Dimaras, Paparrigopoulos, 294-8, 318-22.

${ }^{19}$ Ibid., 227-31. 


\section{PAPARRIGOPOULOS AND BYZANTIUM}

provided, I think, a comforting matrix for the self-understanding of Greek identity and supplied psychological and moral reassurance for a society whose national aspirations far exceeded not only its capabilities but also and more seriously - the moral calibre of its political life, as Paparrigopoulos himself never tired of pointing out. ${ }^{20}$

Paparrigopoulos's rehabilitation of Byzantium, however, and the admirable way in which he integrated it into the continuum of Greek historical development, had a determining influence on Greek political thought. Without ever putting it in writing in the pages of his History, he was instrumental in establishing the image of the Byzantine Empire under the Macedonian and Comnenian dynasties, into a form of teleology for the Greek state: in other words, into an ideal territorial and geographical model which was felt in Greek political culture to be a pointer to the future destiny and mission of Greece.

Paparrigopoulos's historical theory provided an outlet for the articulation of feelings and predispositions which were widespread but inchoate in collective mentality since the liberation of Greece. The substratum of Orthodox culture supplied a living connection with the Byzantine past at the level of popular psychology, but this remained outside the purview of formal cultural expression until about the time of Papadiamantis at the end of the nineteenth century. The reconquest of Constantinople, ${ }^{21}$ the recreation of a 'Greek Empire', ${ }^{22}$ the dream of a larger Greek state in the Balkans, ${ }^{23}$ were often voiced in Greek public debate, especially under the pressure of international crises such as the Crimean War or the confrontation with Bulgarian nationalism after 1870 . But it required a major intellectual achievement such as the History of the Greek Nation before Byzantium could be canonized in Greek political thought as the telos to which the Greek state and Greek destinies were expected to strive to approximate. Within the framework of Paparrigopoulos's historical theory inherited forms of cultural expression, such as those associated with the Orthodox liturgical cycle and the images of emperors, the commemoration of Christian kings, the evocation of the Orthodox kingdom and its earthly seat, Constantinople, which is so powerfully communicated in texts such as the Akathist Hymn, sung every year during Lent and forming such an intimate component of Orthodox worship, acquired new, specifically political meaning. ${ }^{24}$

The new outlook can be felt in the remarks on the Great Idea put forward in a rather unlikely source, a book of recollections from a trip to Sweden and

\footnotetext{
${ }^{20}$ See e.g. Paparrigopoulos, Istoria, V, 736-9, 744-9, 861-5.

${ }^{21}$ E.g. A. Goudas, 'Peri tis Megalis Ideas', Melissa, 2nd series, 1 (1864), 96.

${ }^{22}$ Cf. A. Soutsos, Apomnimoneomata poiitika epi tou Anatolikou Polemou (1857), 11-42.

${ }^{23}$ For a useful survey see E. Skopetea, To protypo vasileio kai $i$ Megali Idea (1988), 273-307.

${ }^{24} \mathrm{Cf}$. Paparrigopoulos's comments on the Akathist and its political significance in Istoria, V, $241-4$.
} 


\section{PASCHALIS M. KITROMILIDES}

Norway by Pavlos Karolidis, Paparrigopoulos's successor in the Chair of the History of the Greek Nation in the University of Athens (on whom see also George Huxley's contribution to the present volume, Chapter 2). Gazing on the grey waves of the North Sea from the seafront at Christiania (now Oslo), and ruminating on Greek nationalism on the shores of a warmer sea on the other side of the European continent, Karolidis dismisses the disdain of foreign critics who viewed the claims of the Great Idea as mere Greek chauvinism. He goes on to attack the arguments of 'a few modernist philosophers of history' among the Greeks, who considered these aspirations to be contrary to the practical needs and prosperity of the nation, and that the claims of Greek nationalism should be limited to the geographical heartlands of classical Hellenism. The Great Idea, in its broader geographical definition, was, according to Karolidis, not 'an expression of pious hopes and of dreams of national grandeur' but 'a historical necessity, an issue of national existence and self-sufficiency'. In this vision of the Great Idea 'the view of the magnificent ruins of the Parthenon could never obscure in Greek national consciousness the historical power of Hagia Sophia'. Abandonment of this vision would amount, in this historian's judgement, to the loss of a wider Hellenic world, including the loss of the 'Panhellenic centre' of the time, Constantinople, as had once happened with other great cities such as Alexandria, Antioch and Ctesiphon, which were once centres of Hellenism. ${ }^{25}$ The historian asked what advantage could accrue to the nation from such a loss, which he connected with the arguments of the critics of the Great Idea.

This was the climate in Greek political thought in the 1890s, in the wake of Paparrigopoulos's redefinition and reordering of Greek history. The wider acceptance and integration of this outlook into the collective 'mentality' of Greek society at the time is reflected neatly in the pages of literary works which may be assumed to register the sensibilities and aspirations prevailing in their cultural environment. From the 1870 s on, beginning with Valaoritis, and with greater density from the 1880 s, with Papadiamantis's early novels The Merchants of Nations (1882) and especially The Gypsy Girl (1884) (see Robert Shannan Peckham's contribution to the present volume, Chapter 8), the imagery of Byzantium, the sense of loss over its fall combined with a resilient pride over its greatness, is increasingly felt in Greek poetry and prose. So we meet with Palamas's great epic creations on Byzantine themes after the turn of the twentieth century and with Penelope Delta's novels, by means of which the solicitude for Byzantium percolated to the widest possible audience, including the younger generations of the reading public. (On these works, see respectively Anthony Hirst's and Marianna Spanaki's papers elsewhere in this volume, Chapters 9 and 10 ).

${ }^{25}$ P. Karolidis, Anamniseis Skandinavikai (1890), 177-81. 


\section{PAPARRIGOPOULOS AND BYZANTIUM}

If, on the basis of what has been said so far, we consider the impact of Paparrigopoulos's work on the Greek mind, we shall also appreciate the extent of one of the endemic confusions about the Great Idea. As a project for the resurrection of the Byzantine Empire in the shape of an expanded modern Greek state, the Great Idea was a late nineteenth-century development and was ideologically to a large extent the product of political manipulations of Paparrigopoulos's historical theories. In these uses of the popularized and vulgarized by-products of the new theories of Greek national continuity the Greek Crown played an active part, trying to enhance its own legitimacy by appropriating some of the symbols of the Byzantine monarchical tradition. The Danish dynasty was a genuine successor to its Bavarian predecessor in dreaming of Constantinople as the rightful seat of Greek monarchy. This dream, however, was not limited to the Crown and to the exponents of royalism. It had a wider appeal, which appeared to be vindicated by the triumphs of the Balkan Wars in 1912-13 and acted as an ideological catalyst which, despite warnings and more sober counsels, drove Greece into Asia Minor in 1919. The power of the Great Idea as a Byzantine idea seems to have taken hold even over Venizelos's better judgement at this juncture. That, however, is another story, in which power politics at the end of the First World War played a more decisive role than the ideological residues of political romanticism in a materialist age.

One tentative conclusion seems to suggest itself, I think, from the reappraisal of the historical record attempted in this paper. As a 'Byzantine idea' the Great Idea was a latecomer to Greek politics, never commanded universal acceptance among the political class and was rather short-lived: its historical trajectory as a politically effective national ideology ran from about the 1880s to 1922, when it ended in tragedy, launching Greece into the twentieth century full of traumas, anxieties and uncertainties. 